\title{
Pengembangan Video Siapa Aku (SIAKU) untuk Meningkatkan Kepercayaan Diri Pada Siswa SMA
}

\author{
Riska Kusuma Hesti*, Adi Atmoko, Irene Maya Simon \\ Universitas Negeri Malang, Jl. Semarang No. 5 Malang, Jawa Timur, Indonesia \\ *Penulis korespondensi, Surel: riskamahesti03@gmail.com
}

Paper received: 2-11-2021; revised: 17-11-2021; accepted: 23-11-2021

\begin{abstract}
This research and development aims to develop a product Who I Am (SIAKU) to increase selfconfidence in high school students. The SIAKU product contains 2 products in the form of videos totaling 3 videos and a guide book for counselors in providing classical guidance services to high school students. The research method used is research and development (R and D) method using the adapted Borg and Gall theory. This research and development procedure includes preliminary studies, product design and development as well as product testing on material expert tests, media expert tests, 2 prospective counselor users and 10 prospective students. Assessment of expert and prospective users to determine product acceptance uses a rating scale based on aspects of accuracy, usability, convenience and product attractiveness. Data analysis on the test results of experts and prospective counselor users uses the numerical average, while the test results of prospective users use an interpreter agreement. Overall test results show that the product Who I am getting a very high rating category and has met the acceptance of the product so that it can be implemented as a medium for counselors in providing classical guidance services to increase self-confidence.
\end{abstract}

Keywords: video education; self-confidence

\begin{abstract}
Abstrak
Penelitian dan pengembangan ini bertujuan untuk mengembangkan produk Siapa Aku (SIAKU) untuk meningkatkan kepercayaan diri pada siswa SMA. Produk SIAKU berisikan 2 produk berupa video yang berjumlahkan 3 video dan buku panduan untuk konselor dalam memberikan layanan bimbingan klasikal kepada siswa SMA. Metode penelitian yang digunakan adalah metode penelitian dan pengembangan atau research and development ( $\mathrm{R}$ and $\mathrm{D})$ dengan menggunakan teori Borg dan Gall yang telah diadaptasi. Prosedur penelitian dan pengembangan ini meliputi studi pendahuluan,rancangan dan pengembangan produk serta uji produk terhadap uji ahli materi, uji ahli media, 2 calon pengguna konselor dan 10 calon pengguna siswa. Penilaian uji ahli dan calon pengguna untuk mengetahui keberterimaan produk menggunakan skala penilaian yang berdasarkan pada aspek ketepatan, kegunaan, kemudahan dan kemenarikan produk. Analisis data pada hasil uji ahli dan calon pengguna konselor menggunakan numerik rerata, sedangkan hasil uji calon pengguna menggunakan inter rater agreement. Keseluruhan hasil uji menunjukkan bahwa produk Siapa Aku mendapatkan kategori penilaian sangat tinggi dan telah memenuhi keberterimaan produk sehingga dapat diimplementasikan sebagai media bagi konselor dalam memberikan layanan bimbingan klasikal untuk meningkatkan kepercayaan diri.
\end{abstract}

Kata kunci: video edukasi; kepercayaan diri

\section{Pendahuluan}

Masa SMA merupakan masa pancaroba bagi seorang remaja dari usia kanak-kanak menuju usia dewasa, yang ditandai dengan perubahan fisik, sosial dan, emosional. Secara umum, perkembangan remaja seringkali dikenal dengan masa yang penuh kesukaran dalam menemukan identitas diri. Apalagi keberagaman terkait penampilan fisik, kemampuan, dan kondisi ekonomi yang berbeda-beda, membuat gejolak terhadap suasana hati remaja kedalam perasaan tertekan. Hal ini dikarenakan perbedaan tersebut, membawa standar dan trend baru 
yang harus dipenuhi remaja, supaya diterima oleh lingkungan maupun teman sebaya. Hurlock (dalam Deni \& Ifdil, 2016) mengungkapkan salah satu dampak remaja yang mendapat tekanan yaitu kepercayaan diri menjadi rendah.

Remaja krisis kepercayaan diri, hal ini dibuktikan dari hasil penelitian Rowan University sebanyak 130 responden, remaja yang aktif bermain media sosial merasa cemas, jika eksistensi diri di media sosial tidak mendapatkan respon sebanyak yang diharapkan (Davies, 2018). Selain pada persoalan fisik, remaja juga kurang memiliki kepercayaan diri pada kemampuan yang dimilikinya. Dilansir dari hitekno.com pada tanggal 16 Desember 2019 menjelaskan adanya siswa yang menggunakan kemajuan teknologi yaitu smartwatch untuk menyontek saat ujian berlangsung (Pratnyawan, 2019). Penyalahgunaan smartwatch pada kalangan pelajar, menjadi bukti bahwa siswa masih memiliki keraguan terhadap kemampuannya.

Rendahnya kepercayaan diri, dapat menghambat penyelesaian tugas perkembangan remaja, yaitu kematangan dalam mencapai pola hubungan baru dengan teman sebaya, atas dasar etika moral yang berlaku di masyarakat. Perkembangan tugas remaja yang tidak terselesaikan dengan baik, akan mempengaruhi tugas perkembangan selanjutnya, termasuk perkembangan karakter dan mental seseorang. Apalagi jika remaja seringkali berpikir negatif, bahkan mengalami ketakutan tanpa sebab, sehingga membuat remaja melakukan pembatasan diri dalam menampilkan diri nya (Rahayu, 2013). Oleh karena itu, peningkatan kepercayaan diri bagi masa depan remaja sangatlah penting untuk membentuk mental dan karakter seseorang dalam menyikapi setiap tantangan dengan lebih realistis (Rahayu, 2013).

Hasil penelitian Wiranatha \& Supriyadi (2015) sebesar 241 siswa (49\%) memiliki kepercayaan diri rendah, artinya secara umum remaja putri mengalami ketidakyakinan dengan kemampuannya. Sedangkan sebesar 200 siswa (20,7\%) memiliki kepercayaan diri tinggi, 31 siswa (6,3\%) memiliki kepercayaan diri sangat tinggi, serta 20 siswa $(4,1 \%)$ memiliki kepercayaan diri sangat rendah. Hal ini berarti bahwa ketidakyakinan dan pandangan negatif terhadap kemampuan diri sendiri, sebagian besar dimiliki oleh remaja putri. Ketidakyakinan terkait kelebihan dan kekurangan, membuat seseorang beranggapan bahwa dirinya tidak berharga dan putus asa atas kondisi diri nya dalam memenuhi standar masyarakat (Livia, 2020). Permasalahan tersebut, menunjukkan bahwa masih terdapat krisis kepercayaan diri remaja yang belum terselesaikan.

Kepercayaan diri merupakan bagian utama yang harus dibangun oleh remaja untuk mengembangkan penilaian positif dalam menghadapi tantangan. Sebagaimana dimasa mendatang, remaja harus sadar atas tanggung jawab terhadap keputusan yang diambilnya. Remaja yang dapat dikatakan memiliki kepercayaan diri jika ia mampu bertindak dengan baik bagi diri nya sesuai bidang dan kemampuannya (Rahayu, 2013). Sesuai dengan standar kompetensi kemandirian peserta didik (SKKPD) Kepercayaan diri termasuk dalam pengembangan diri pada bidang pribadi. Aspek tersebut, sangatlah penting bagi remaja dalam meningkatkan kepercayaan diri, karena sudah sepatutnya di usia remaja harus menerima keunikan diri dengan segala bentuk kelebihan dan kekurangan (Santoso, 2011)

Menyikapi permasalahan yang terjadi pada remaja mengenai rendahnya kepercayaan diri, maka dibutuhkan konselor sebagai fasilitator untuk memberikan informasi melalui layanan bimbingan terkait pentingnya menumbuhkan kepercayaan diri pada siswa. Berdasarkan hasil wawancara terhadap konselor di SMAN 7 Malang bahwa layanan bimbingan dan konseling kurang efektif karena dilakukan saat jam kosong. Hal ini dikarenakan pemberian 
layanan BK mengalami keterbatasan waktu, ruang, daya indera dan kejelasan dalam menyampaikan pesan (Sari, 2020). Apalagi metode yang sering digunakan dalam bimbingan klasikal yakni tanya jawab dan ekspositori, sehingga antusias siswa mengikuti kegiatan layanan bimbingan sangat kurang. Oleh karena itu, diperlukan alternatif solusi untuk memfasilitasi siswa secara menyeluruh dalam meningkatkan kepercayaan diri melalui layanan bimbingan klasikal dengan menggunakan media yang lebih menarik dan efektif penggunaanya pada layanan bimbingan.

Media BK diartikan sebagai sarana penyampaian pesan dan interaksi antara konselor dengan siswa pada layanan BK, agar penggunaannya mudah diserap, untuk menunjang proses pemberian bantuan. Sebagaimana penggunaan media dalam BK dapat memperjelas penyajian informasi, supaya tidak terlalu verbalistis. Salah satu bentuk media yang dapat diaplikasikan pada bidang bimbingan dan konseling yakni media video. Penyajian media video dalam layanan bimbingan dan konseling, berguna sebagai pemberian rangsangan terhadap indera pendengaran dan penglihatan. Sebagaimana media video didesain menggunakan ilustrasi visual secara verbal maupun nonverbal, yang disertai auditori (Basri, 2010).

Menurut Achsin (Basri, 2010) bahwa sebesar 90\% indera penglihatan memiliki pengaruh terhadap hasil belajar, melalui indera dengar hanya sebesar $5 \%$ serta hasil belajar dengan indera lainnya memiliki pengaruh sebesar $5 \%$. Selaras dengan pernyataan Levie an Levie bahwa hasil belajar dan pemahaman yang lebih baik dalam menghubungkan fakta serta konsep untuk mengenali dan mengingat dipengaruhi dari stimulus visual(dalam Arsyad, dalam Basri, 2010). Hal ini juga diperkuat oleh hasil penelitian Listiyanto (2019) bahwa dengan penggunaan video edukasi pada pelajaran sejarah sebesar 44,1\% mampu memberikan motivasi belajar secara signifikan dan sebesar 55,9\% dipengaruhi oleh faktor lain. Selaras dengan penelitian Dari hasil penelitian tersebut, penggunaan media video memiliki dampak dan pengaruh yang besar terhadap proses pembelajaran bagi siswa SMA.

Hasil penelitian Rahman dkk (2019) mengungkapkan bahwa pemberian layanan bimbingan dan konseling kepada siswa dengan menggunakan media video dapat mengurangi perilaku bullying. Hal ini dapat dilihat dari tingkat ketepatan penayangan media video kepada siswa, yaitu terjadi perubahan tingkat perilaku bullying yang awalnya $81 \%$ menjadi $28 \%$. Dari hasil penelitian terdahulu, maka pengembangan media video untuk meningkatkan kepercayaan diri siswa pada layanan BK guna memberikan bantuan kepada siswa SMA memiliki daya tarik.

Merujuk dari data penelitian di lapangan dan fenomena terkait rendahnya kepercayaan diri terhadap remaja, peneliti mengembangkan produk Siapa Aku (SIAKU) yang bertujuan untuk meningkatkan kepercayaan diri pada siswa SMA. Dalam produk SIAKU terdapat dua produk berupa 3 video SIAKU dan buku panduan konselor. Video SIAKU digunakan untuk memfasilitasi layanan bimbingan sebagai sarana informasi kepada siswa mengenai kepercayaan diri, sedangkan buku panduan diperuntukkan bagi konselor sebagai pedoman layanan dengan media SIAKU.

\section{Metode}

Jenis penelitian ini, merupakan penelitian pengembangan atau disebut dengan Research and Development dengan model penelitian Borg \& Gall yang telah diadaptasi untuk disesuaikan dengan kebutuhan peneliti yaitu; (1) Research and information collecting, peneliti mengkaji studi literatur terkait kepercayaan diri dan melakukan need assessment melalui observasi dan 
wawancara dengan konselor sekolah, untuk mengumpulkan data terkait peningkatan kepercayaan diri. (2) Planning, peneliti menentukan tujuan pengembangan produk Siapa Aku dan melakukan perancangan desain produk beserta materi yang digunakan. (3) Develop preliminary form of product, mengembangkan produk SIAKU, berupa video dan buku panduan untuk konselor berdasarkan rancangan produk. (4) Preliminary field testing, melakukan uji keberterimaan produk dari ahli materi, ahli media dan calon pengguna yakni dua konselor sekolah. (5) Main product revision, peneliti melakukan revisi berdasarkan validasi ahli maupun calon pengguna konselor. (6) Main field testing, melakukan uji calon pengguna dengan melibatkan 10 siswa SMA sebagai bahan acuan dalam perbaikan produk. (7) Operational product revision and final product, peneliti melakukan perbaikan berdasarkan uji coba terbatas kepada 10 siswa untuk menghasilkan produk akhir dari Media SIAKU.

Subjek penelitian dan pengembangan terdiri dari 1 ahli materi, 1 ahli media, 2 calon pengguna (konselor) dan 10 siswa calon pengguna (konseli). Instrumen yang digunakan yakni skala penilaian untuk mengetahui penerimaan produk yang meliputi aspek ketepatan, aspek kegunaan, aspek kemudahan, dan aspek kemenarikan dari produk Siapa Aku (SIAKU). Hasil dari penilaian ahli dan calon pengguna tersebut, dianalisis menggunakan dua teknik analisis data yakni analisis data numeric rerata digunakan untuk analisis data hasil ahli materi, ahli media dan calon pengguna (konseli). Sedangkan inter-rater-agreement digunakan pada analisis data hasil uji calon pengguna (konselor).

\section{Hasil dan Pembahasan}

\subsection{Hasil}

Penelitian dan pengembangan ini menghasilkan produk berupa video animasi Siapa Aku (SIAKU) dan buku panduan untuk konselor yang didasarkan pada kajian pustaka dan kebutuhan dilapangan. Berdasarkan dari hasil wawancara yang diperoleh dengan konselor SMAN 7 Malang bahwa media BK terkait peningkatan kepercayaan diri layanan bimbingan yang dilakukan oleh konselor di SMA tersebut, kurang efektif karena dilakukan saat jam kosong. Konselor memaparkan bahwa belum terjadwalnya jam BK saat pandemi membuat antusias siswa dalam mengikuti kegiatan layanan secara fleksibel menurun. Bahkan penerapan metode dalam layanan bimbingan hanya sebatas tanya jawab dan ekspositori. Selain itu pengembangan media di SMAN 7 Malang yang dapat menunjang layanan bimbingan dan konseling sangat terbatas, terutama mengenai media dalam meningkatkan kepercayaan diri. Melihat rendahnya kepercayaan diri siswa ditengah pandemic, konselor memaparkan bahwa dirasa penting memberikan informasi melalui media yang efektif untuk meningkatkan kepercayaan diri siswa.

Pengembangan produk SIAKU menghasilkan video edukasi dan buku panduan untuk konselor. Pada produk video SIAKU menggunakan jenis video berupa motion graphic dengan durasi 5-10 menit pada setiap video. Video SIAKU terdiri dari tiga video yang masing-masing memiliki fokus terhadap kepercayaan diri, yakni video SIAKU 1 berjudul "This is me" yang berfokus pada kepercayaan diri berupa mengenali diri dan membuat standar atas pencapaian tujuan hidup. Video SIAKU 2, dengan judul "My Self-Introspection" yang berfokus pada kepercayaan diri berupa mengintrospeksi diri dan mampu mengatasi perasaan tertekan, kecewa serta ketidakmampuan. Video SIAKU 3 dengan judul "Keep calm and stay positive" yang 
berfokus pada kepercayaan diri berupa mampu mengelola perasaan cemas, bersikap tenang dalam menghadapi sesuatu serta mampu berfikir positif.

Produk kedua yakni buku panduan konselor yang memiliki ukuran A4 dengan penggunaan bahan kertas art paper 150 gram. Buku panduan tersebut memiliki 46 halaman yang meliputi; 1) bab I pendahuluan berisi mengenai latar belakang, tujuan dan sasaran pengguna, 2) bab II konsep dasar berisi mengenai materi kepercayaan diri dan siapa aku (SIAKU), 3) bab III petunjuk penggunaan produk secara umum dan khusus, 4) bab IV berisi mengenai penjelasan video, keterkaitan kepercayaan diri dalam video Siapa Aku (SIAKU) dan manfaat video Siapa Aku (SIAKU), 5) bab V berisi rencana pelaksanaan layanan (RPL) pada setiap pertemuan, 6) bab VI berisi penutup.

Berdasarkan hasil penilaian yang diperoleh dari ahli materi mendapatkan indeks validitas pada aspek ketepatan memperoleh sebesar 0,91, aspek kegunaan memperoleh sebesar 1,00, aspek kemudahan memperoleh sebesar 0,97, aspek kemenarikan memperoleh sebesar 1,00. Dari hasil keempat aspek menunjukkan bahwa produk pengembangan media Siapa Aku (SIAKU) dinilai sangat tepat, sangat berguna, sangat mudah, dan sangat menarik untuk diterapkan karena indeks penilaian yang masuk dalam rentang 0,76 - 1,00. Data deskriptif yang diperoleh yakni pada buku panduan bagian petunjuk umum poin 5 akan lebih tepat jika dijelaskan secara detail dan materi yang disusun di setiap RPL BK disesuaikan dengan indikator yang akan dicapai.

Pada penilaian uji ahli media mendapatkan indeks penilaian dari aspek ketepatan sebesar 0,91, aspek kegunaan memperoleh sebesar 1,00, aspek kemudahan sebesar 1,00 dan aspek kemenarikan memperoleh penilaian sebesar 1,00. Dari hasil keempat aspek menunjukkan bahwa produk pengembangan media Siapa Aku (SIAKU) memiliki keberterimaan yang tinggi yakni sangat tepat, sangat berguna, sangat mudah, dan sangat menarik untuk diterapkan karena indeks penilaian yang masuk dalam rentang 0,76-1,00. Data deskriptif yang diperoleh yakni secara umum video sudah bagus untuk mengajarkan kepercayaan diri, namun perlu ditambahkan refleksi pengalaman konseli berdasarkan video tersebut. Pada video "Keep calm and stay positive" akan lebih tepat jika ditambahkan bagaimana tokoh bisa mengatasi kecemasan dan mengubah cara berpikir positif. Kemudian tampilan desain panduan sebaiknya gambar 1 orang yang menggambarkan mengenali diri, karena gambar sampul lebih menunjukkan komunikasi dengan orang lain.

Uji calon pengguna dilakukan kepada 2 konselor yang telah memenuhi kriteria penelitian, hasil uji diperoleh indeks 1 yang dapat diartikan bahwa penilaian berada pada kategori sangat tinggi yaitu sangat tepat, sangat berguna, sangat mudah dan sangat menarik. Data deskriptif yang diperoleh pada konselor 1 yakni; video edukasi sudah baik, bahasa yang digunakan mudah dipahami untuk jenjang SMA dan video yang dikembangkan sudah berkaitan dengan kepercayaan diri serta bersifat bersifat motivasi. Sedangkan pada konselor 2, secara keseluruhan tampilan panduan dan video sudah bagus, video juga sudah menampilkan masalah kepercayaan diri sesuai dengan tujuan yang ingin dicapai. Selain itu, warna subtitle video kurang terlihat karena berwarna putih. Intonasi dubbing sudah baik, hanya perlu ditingkatkan intonasi pada beberapa percakapan.

Pada penilaian uji calon pengguna yang dilakukan kepada 10 siswa SMAN 7 Malang mendapatkan hasil data keseluruhan pada indeks penilaian dari aspek ketepatan sebesar 0,94, aspek kegunaan memperoleh sebesar 0,97, aspek kemudahan sebesar 0,99 dan aspek 
kemenarikan memperoleh penilaian sebesar 0,97. Dari hasil keempat aspek menunjukkan bahwa produk pengembangan media Siapa Aku (SIAKU) memiliki keberterimaan yang sangat tinggi yakni sangat tepat, sangat berguna, sangat mudah, dan sangat menarik untuk diterapkan karena indeks penilaian yang masuk dalam rentang $0,76-1,00$. Data deskriptif yang diperoleh yakni secara umum tampilan video secara keseluruhan yang telah dikembangkan sudah bagus, materi yang telah diangkat sangat menarik dan mudah dipahami. Namun dalam pengembangan animasi perlu ditingkatkan lagi terkait dubbing dan desain karakternya.

\subsection{Pembahasan}

Menyikapi permasalahan yang terjadi pada siswa mengenai rendahnya kepercayaan diri. Konselor sebagai fasilitator mempunyai tanggung jawab untuk mengentaskan permasalahan tersebut, melalui layanan bimbingan dan konseling, dengan memberikan informasi terkait pentingnya peningkatan kepercayaan diri. Hal ini, berguna untuk mengfasilitasi siswa dalam mengembangkan segenap potensi yang dimiliki dengan penuh keyakinan dan rasa tanggung jawab. Sebagaimana yang telah tercantum pada Standar Kompetensi Kemandirian Peserta Didik (SKKPD), bahwa salah satu perkembangan aspek remaja yang harus terpenuhi adalah pengembangan diri. Aspek tersebut, sangatlah penting bagi remaja dalam meningkatkan kepercayaan diri, karena sudah sepatutnya di usia remaja harus menerima keunikan diri dengan segala bentuk kelebihan dan kekurangan (Santoso, 2011).

Ghufron \& Risnawati (2017) menyampaikan bahwa kepercayaan diri merupakan keyakinan individu dalam melakukan suatu tindakan, sesuai dengan karakteristik pribadi seseorang berdasarkan kemampuan dan rasa tanggung jawab. Individu yang memiliki kepercayaan diri memiliki potensi menjadi pribadi mandiri tanpa terlalu khawatir terhadap apa yang menjadi tantangan dalam hidupnya. Pearce (dalam Rahayu, 2013) secara khusus kepercayaan diri bukanlah suatu sikap dalam menghindari kondisi yang penuh tekanan, namun kepercayaan diri adalah usaha seseorang dalam melakukan sebuah tindakan yang dihadapi dengan penuh keyakinan.

Produk Siapa Aku (SIAKU) merupakan produk berupa video edukasi yang berjumlahkan 3 video yang dikembangkan untuk media penunjang bagi konselor dalam memberikan layanan bimbingan klasikal. Video SIAKU dikembangkan semenarik mungkin dengan menggunakan video berupa animasi yang bersifat reflektif dan motivasi, untuk memberikan pemahaman terkait pentingnya peningkatan kepercayaan diri. Selaras dengan penelitian Listiyanto (2019) bahwa penggunaan video edukasi pada pelajaran selarah, mampu memberikan motivasi belajar secara signifikan. Menurut Hadi (2017) adanya media video untuk proses pemberian layanan bimbingan klasikal dinilai positif dan efektif, karena memiliki pengaruh serta daya tarik yang besar terhadap siswa SMA.

Pemilihan video sebagai media untuk meningkatkan kepercayaan diri juga ditujukan agar siswa dapat melihat model yakni beberapa kisah remaja yang mencerminkan ciri-ciri pribadi yang percaya diri. Mayer mengungkapkan bahwa adanya multimedia dalam pembelajaran dapat membawa pengaruh terhadap diri siswa dengan baik melalui teks dan ilustrasi animasi, daripada hanya belajar menggunakan teks saja (dalam Pradana \& Hermawan, 2019). Dengan mengamati suatu perilaku melalui video atau rekaman slide dapat membawa seseorang mengubah pola fikirnya, sehingga membentuk perilaku yang baru. Oleh 
karena itu, dengan cara meneladani tayangan video SIAKU dapat membawa seseorang meningkatkan kepercayaan diri.

Video edukasi SIAKU berisikan materi terkait ciri-ciri seseorang yang memiliki kepercayaan diri. Oleh Karena itu, pada isis video juga berisikan mengenai peningkatan kepercayaan diri. Pada setiap video memiliki focus aspek kepercayaan diri yang berbeda-beda yakni berupa 1) mengenali diri, 2) membuat standar pencapaian, 3) mengelola perasaan tertekan, kecewa dan ketidakmampuan, 4) intropeksi diri, 5) mengelola perasaan cemas, 6) bersikap tenang dalam menghadapi sesuatu, 7) mampu berfikir positif (Komara, 2016).

Selain video edukasi, peneliti juga mengembangkan buku panduan yang ditujukan sebagai pedoman bagi konselor dalam memberikan layanan bimbingan klasikal. Adapun tujuan dari pengembangan buku panduan ini, supaya konselor memiliki pedoman dalam memberikan layanan bimbingan klasikal. Penerapan layanan bimbingan dengan menggunakan setting klasikal ini, bersifat pemahaman, sehingga ditujukan untuk seluruh siswa, mengingat layanan bimbingan klasikal merupakan layanan dasar yang menyajikan informasi terkait pentingnya peningkatan kepercayaan diri. Levied an Levie mengungkapkan bahwa bahwa hasil belajar dan pemahaman yang lebih baik dalam menghubungkan fakta serta konsep untuk mengenali dan mengingat dipengaruhi dari stimulus visual (dalam Arsyad, dalam Basri, 2010).

Berdasarkan hasil penilaian yang diperoleh dari uji ahli, media Siapa Aku (SIAKU) memperoleh keberterimaan produk yang tinggi yakni sangat tepat, sangat berguna, sangat mudah dan sangat menarik. Adapun keunggulan dari media video adalah penggunaan media dalam layanan BK dapat merangsang perilaku, minat dan perasaan individu keranah yang lebih baik (Prasetiawan dan Alhadi 2018). Hal ini selaras dengan data deskriptif yang diperoleh dari uji ahli media yang memaparkan bahwa video yang digunakan sangat tepat untuk megajarkan kepada siswa dalam meningkatkan kepercayaan diri. Selain itu, dari hasil uji calon pengguna konselor 1 bahwa dalam video SIAKU sudah bersifat motivasi, sehingga berkaitan dengan kepercayaan diri. Kemudian dari hasil uji calon pengguna konselor 2 juga memaparkan bahwa secara keseluruhan video sudah menampilan masalah kepercayaan diri sesuai dengan tujuan yang ingin dicapai.

Keunggulan selanjutnya dari video SIAKU yakni dapat memperjelas penyampaian pesan ditengah keterbatasan terkait waktu, ruang dan daya indera siswa (Sari, 2020). Pemberian layanan dengan menggunakan video SIAKU kepada siswa dalam penerapannya dapat diulang dan diberhentikan sesuai kebutuhan konselor sebagai bahan diskusi serta refleksi. Dengan demikian siswa dapat berdiskusi dengan teman satu kelompok untuk menyampaikan pendapat terkait pengalaman dari tayangan video SIAKU. Selain itu, penyajian media video dalam layanan bimbingan dan konseling, berguna sebagai pemberian rangsangan terhadap indera pendengaran dan penglihatan. Sebagaimana media video didesain menggunakan ilustrasi visual secara verbal maupun nonverbal, yang disertai auditori (Basri, 2010). Hasil penelitian Rahman dkk (2019) menyatakan bahwa pengembangan media video memiliki daya tarik untuk layanan Bimbingan dan Konseling bagi siswa SMA.

Pada hasil uji calon pengguna konselor memperoleh hasil keberterimaan produk yang tinggi dari aspek ketepatan, aspek kegunaan, aspek kemudahan dan aspek kemenarikan produk. Produk dinilai sangat menarik, mudah dipahami dari segi bahasa yang digunakan, secara keseluruhan sudah baik dan layak untuk diimplementasikan. Bahkan produk juga sangat layak jika disampaikan kepada siswa serta dibagikan ke media sosial sebagai bahan 
pembelajaran untuk meningkatkan kepercayaan diri. Adapun saran yang diberikan oleh uji pengguna terhadap produk yaitu warna subtitle video kurang terlihat karena berwarna putih serta intonasi dubbing perlu ditingkatkan pada beberapa percakapan. Dalam hal ini, peneliti perlu memperbaiki subtitle video dengan warna yang gelap yakni hitam untuk memperjelas.

Pada penilaian uji calon pengguna siswa hasil keempat aspek menunjukkan bahwa produk pengembangan media Siapa Aku (SIAKU) memiliki keberterimaan yang sangat tinggi yakni sangat tepat, sangat berguna, sangat mudah, dan sangat menarik untuk diterapkan. Apabila produk digunakan sebagai media penunjang layanan bimbingan kepada seluruh siswa dan dibagikan ke sosial media akan sangat bermanfaat untuk meningkatkan kepercayaan diri. adapun masukan yang diperoleh dari calon pengguna siswa yakni secara umum tampilan video secara keseluruhan yang telah dikembangkan sudah bagus, materi yang telah diangkat sangat menarik dan mudah dipahami. Namun dalam pengembangan animasi perlu ditingkatkan lagi terkait dubbing dan desain karakternya.

Berdasarkan keseluruhan uji dari hasil uji ahli materi, uji ahli media, uji calon pengguna konselor dan uji calon penggunan siswa, media SIAKU sebagai media konselor dalam memberikan layanan bimbingan klasikal untuk meningkatkan kepercayaan diri, mendapatkan penilaian keberterimaan produk yang sangat tinggi. Keberterimaan produk tersebut dinilai sangat tinggi dari aspek ketepatan, kegunaan, kemudahan dan kelayakan produk. Dalam hal ini, media SIAKU dapat digunakan atau diimplementasikan oleh konselor dalam memberikan layanan bimbingan klasikal untuk meningkatkan kepercayaan diri siswa.

\section{Simpulan}

Pengembangan produk Siapa Aku sebagai media bagi konselor dalam memberikan layanan bimbingan klasikal untuk meningkatkan kepercayaan diri pada siswa SMA telah memenuhi kriteria keberterimaan produk dari segi aspek ketepatan, aspek kegunaan, aspek kemudahan dan aspek kemenarikan produk. Produk memperoleh keberterimaan yang tinggi sehingga produk dapat digunakan atau diimplementasikan sebagai media bagi konselor dalam memberikan layanan bimbingan klasikal kepada siswa SMA. Dalam penggunaan produk, saran bagi konselor yakni penggunaan produk ditujukan untuk konselor yang memiliki kualifikasi minimal S1 Bimbingan dan Konseling serta diharapkan memiliki pengetahuan yang cukup terkait ciri-ciri kepercayaan diri sebelum memberikan layanan bimbingan kepada siswa, Karena media SIAKU hanya sebagai media penunjang dalam menampilkan materi, gambaran dan ilustrasi kepercayaan diri. Pada penelitian selanjutnya, temuan penelitian ini dapat dijadikan sebagai acuan untuk menguji keefektifan media Siapa Aku (SIAKU) sebagai media untuk meningkatkan kepercayaan diri pada siswa SMA.

\section{Daftar Rujukan}

Basri, A. S. H. (2010). Peran Media Dalam Layanan Bimbingan. Jurnal Dakwah, XI(1), 23-41. Retrieved from http://ejournal.uin-suka.ac.id/dakwah/jurnaldakwah/article/view/402

Davies, A. P. (2018). Remaja Krisis Percaya Diri, Psikolog: Dukung Secara Emosional. Retrieved February 21, 2021, from tempo.co website: https://gaya.tempo.co/read/1054871/remaja-krisis-percaya-diripsikolog-dukung-secara-emosional/full\&view=ok

Deni, A. U., \& Ifdil. (2016). Konsep Kepercayaan Diri Remaja Putri. Jurnal Educatio: Jurnal Pendidikan Indonesia, $2(2), 43-52$.

Ghufron, M. N., \& Risnawati, R. S. (2017). Teori-Teori Psikologi. Yogyakarta: Ar-Ruzz Media.

Hadi, S. (2017). Efektivitas Penggunaan Video Sebagai Media. Prosiding TEP \& PDs, Tema: 1 No, 96-102. 
Komara, I. B. (2016). Hubungan antara Kepercayaan Diri dengan Prestasi Belajar dan Perencanaan Karir Siswa SMP. PSIKOPEDAGOGIA Jurnal Bimbingan dan Konseling, 5(1), 33. https://doi.org/10.12928/psikopedagogia.v5i1.4474

Listiyanto, T. (2019). Pengaruh Pemanfaatan Video Edukasi Sebagai Media Pembelajaran Terhadap Motivasi Belajar Sejarah Siswa Kelas Xi/Ips Di Sma Negeri 1 Bandar Tahun Ajaran 2014/2015. Journal of Chemical Information and Modeling, 53(9), 1689-1699. Retrieved from http://repository.uinjkt.ac.id/dspace/handle/123456789/29026

Livia. (2020). Eila Nurhasanah: Belajar Menghargai Diri Sendiri Setelah Terus Menerima Hinaan Fisik Sejak Remaja \#InspirasiCantik. Stylo.Id. Retrieved from https://stylo.grid.id/read/142321024/eilanurhasanah-belajar-menghargai-diri-sendiri-setelah-terus-menerima-hinaan-fisik-sejak-remajainspirasicantik?page=all

Pradana, D. A., \& Hermawan, C. (2019). Desain Dan Implementasi : Audio Video on Demand ( Avod ) Untuk Peningkatan Kemampuan Dan Kepercayaan Diri Mahasiswa. 2(August 1945), 1737-1743.

Prasetiawan, H., \& Alhadi, S. (2018). Pemanfaatan Media Bimbingan dan Konseling di Sekolah Menengah Kejuruan Muhammadiyah se-Kota Yogyakarta. Jurnal Kajian Bimbingan dan Konseling, 3(2), 87-98. https://doi.org/10.17977/um001v3i22018p087

Pratnyawan, A. (2019). Viral Siswa Gunakan Smartwatch untuk Menyontek, Guru Harus Perhatian. Hitekno.Com. Retrieved from https://www.hitekno.com/gadget/2019/12/16/114417/viral-siswagunakan-smartwatch-untuk-menyontek-guru-harus-perhatian

Rahayu, A. (2013). Menumbuhkan Kepercayaan Diri Melalui Kegiatan Bercerita. Jakarta: Indeks.

Rahman, A., Aryani, F., \& Sinring, A. (2019). Pengembangan Media Video Bimbingan Konseling untuk Mengurangi Perilaku Bullying. Jurnal Psikologi Pendidikan Dan Konseling: Jurnal Kajian Psikologi Pendidikan Dan Bimbingan Konseling, 4(2), 129. https://doi.org/10.26858/jpkk.v4i2.5002

Santoso, D. B. (2011). Dasar-dasar Bimbingan dan Konseling. Malang: Tanpa Penerbit.

Sari, W. P. (2020). Pengembangan media videoscribe pada bimbingan klasikal dengan materi gaya belajar di sma negeri 1 indralaya selatan skripsi. 